\title{
PENGARUH FIXED ASSETS TURNOVER, QUICK RATIO DAN TIMES INTEREST EARNED TERHADAP RETURN ON ASSET PADA PERUSAHAAN SUB SEKTOR PROPERTY DAN REAL ESTATE YANG TERDAFTAR DI BURSA EFEK INDONESIA PERIODE 2013-2017
}

\author{
Oleh : \\ Victor Erlian ${ }^{1)}$, dan Holfian Daulat Tambun ${ }^{2)}$ \\ Universitas Prima Indonesia, Medan ${ }^{1,2}$ \\ E-Mail : \\ viktor_cola@yahoo.co.id ${ }^{1)}$, holfiandts@yahoo.co.id ${ }^{2)}$
}

\begin{abstract}
In develoving national economy, property sector has an important role. This sector is as strategic as other sectors, such as agriculture, industry, trade, services, and others. Property with a focus in the field of housing and construction is one of the sectors absorbing large amounts of labor and the multiplier effect is quite long. Therefore, this sector has big effect to support the development of economy sectors. This research aims at testing and analyzing the effect of Fixed Assets Turnover, Quick Ratio, and Times Interest Earned on Return On Asset on sub-sector company of property and real estate registered on Indonesia Stock Exchange in 2013-2017 period. Data analyzing was done by Software SPSS 22. Method of data analysis used is descriptive statistics, classic assumption test, multiple linear regression analysis and hypothesis testing (partial test, simultaneous test and coefficient of determination). The results of the study prove that each (partial) shows that Fixed Assets Turnover has no significant effect. Quick Ratio has no significant effect. Times Interest Earned has a positive and significant effect. Simultaneously, the variables Fixed Assets Turnover, Quick Ratio, and Times Interest Earned have a positive and significant effect on Return On Assets, with a coefficient of determination of $59.2 \%$. The remaining $40.8 \%$ is the influence of the variables described outside in this study.
\end{abstract}

Keywords: :Fixed Assets Turnover (FAT), Quick Ratio (QR), Times Interest Earned (TIE), Return On Asset (ROA)

\section{PENDAhUluAN}

\section{Latar Belakang Masalah}

Dalam pembangunan

perekonomian nasional sektor properti memiliki peran penting. Karena itu sektor ini punya dampak besar untuk menarik dan mendorong perkembangan sektor-sektor ekonomi lainnya (www.kanalsatu.com).

Pengukuran kinerja keuangan suatu perusahaan dapat dilihat melalui tingkat profitabilitas yang dihasilkan. Profitabilitas mencerminkan kemampuan perusahaan untuk menghasilkan laba. Salah satu indikator rmengukur profitabilitas adalah dengan menggunakan Return on Asset (ROA).

$$
\text { Fixed Assets Turnover }
$$

(Perputaran aktiva tetap) adalah posisi aktiva tetap dan taksiran waktu perputaran aktiva tetap dapat dinilai dengan menghitung tingkat perputaran 
aktiva tetap yaitu dengan membagi penjualan dengan total aktiva tetap bersih.

Rasio likuiditas menunjukkan kemampuan perusahaan untuk membayar kewajiban finansialnya dengan segera. Rasio ini berguna untuk mengetahui seberapa besar asset likuid yang bias diubah menjadi kas. Salah satu rasio likuiditas yang umum digunakan dalam melakukan penelitian adalah quick ratio.

Rasio cakupan bunga / Time Interest Earned (TIE) diartikan sebagai gambaran perusahaan dalam kesanggupannya menyelesaikan beban bunga, yang diukur dengan membandingkan laba operasi dengan beban bunganya.

Berdasarkan uraian yang telah dijelaskan di atas, maka peneliti memutuskan untuk melakukan penelitian dengan judul "Pengaruh Fixed Assets Turnover, Quick Ratio, Dan Times Interest Earned Terhadap Return On Asset Pada Perusahaan Sub Sektor Property Dan Real Estate Yang Terdaftar Di BEI Periode 20132017'.

\section{Identifikasi Masalah}

Berdasarkan uraian diatas maka, dapat diidentifikasi masalah penelitian sebagai berikut:

1. Peningkatan Fixed Assets Turnover tidak selalu diikuti dengan peningkatan Return On Asset pada perusahaan sub sektor Property dan Real Estate yang terdaftar di BEI periode 2013 - 2017.

2. PeningkatanQuick Ratio tidak selalu diikuti dengan peningkatan Return On Asset pada perusahaan sub sektor
Property dan Real Estate yang terdaftar di BEI periode 2013 2017.

3. Peningkatan Times Interest Earned tidak selalu diikuti dengan peningkatan Return On Asset pada perusahaan sub sektor Property dan Real Estate yang terdaftar di BEI periode 2013 - 2017.

4. Peningkatan Fixed Assets Turnover, Quick Ratio, dan Times Interest Earned tidak selalu diikuti dengan peningkatan Return On Asset pada perusahaan sub sektor Property dan Real Estate yang terdaftar di BEI periode 2013 2017.

\section{Perumusan Masalah}

Sesuai dengan identifikasi masalah yang telah di kemukakan, maka peneliti merumuskan masalah dalam penelitian ini adalah sebagai berikut:

1. Bagaimana pengaruh Fixed Assets Turnover terhadap Return On Asset pada perusahaan sub sektor Property dan Real Estate yang terdaftar di BEI periode 2013 - 2017 ?

2. Bagaimana pengaruh Quick Ratio terhadap Return On Asset pada perusahaan sub sektor Property dan Real Estate yang terdaftar di BEI periode 2013 2017 ?

3. Bagaimana pengaruh Times Interest Earned terhadap Return On Asset pada perusahaan sub sektor Property dan Real Estate yang terdaftar di BEI periode $2013-2017$ ?

4. Bagaimana pengaruh Fixed Assets Turnover, Quick Ratio, 
dan Times Interest Earned terhadap Return On Asset pada perusahaan sub sektor Property dan Real Estate yang terdaftar di BEI periode 2013 - 2017 ?

\section{Tujuan Penelitian}

Tujuan penelitian ini untuk :

1. Untuk menguji dan menganalisis pengaruh Fixed Assets Turnover, terhadap Return On Asset pada perusahaan sub sektor Property dan Real Estate yang terdaftar di BEI periode 2013 - 2017.

2. Untuk menguji dan menganalisis pengaruh Quick Ratio terhadap Return On Asset pada perusahaan sub sektor Property dan Real Estate yang terdaftar di BEI periode 2013 - 2017.

3. Untuk menguji dan menganalisis pengaruh Times Interest Earned terhadap Return On Asset pada perusahaan sub sektor Property dan Real Estate yang terdaftar di BEI periode 2013 - 2017.

4. Untuk menguji dan menganalisis pengaruh Fixed Assets Turnover, Quick Ratio, dan Times Interest Earned terhadap Return On Asset pada perusahaan sub sektor Property dan Real Estate yang terdaftar di BEI periode 2013 - 2017.

\section{Perngertian Fixed Asset Turnover}

Menurut Hery (2017:185), perputaran aset tetap merupakan rasio yang digunakan untuk mengukur keefektifan aset tetap yang dimiliki perusahaan dalam menghasilkan penjualan atau dengan kata lain untuk mengukur seberapa efektif kapasitas aset tetap turut berkontribusi menciptakan penjualan.Perputaran aset tetap yang rendah berarti perusahaan memiliki kelebihan kapasitas aset tetap, di mana aset tetap yang ada belum dimanfaatkan secara maksimal menciptakan penjualan / pendapat perusahaan.

Menurut Hermanto (2015:117), rumus rasio perputaran aset tetap (fixed asset turnover):

$$
\mathrm{FAT}=\frac{\text { Penjualan }}{\text { Jumlah aktiva tetap }}
$$

\section{Pengertian Quick Ratio}

Menurut Kasmir (2012:136), quick ratio merupakan rasio yang digunakan untuk menunjukan kemampuan perusahaan dalam memenuhi atau membayar kewajiban atau utang lancar (utang jangka pendek) dengan aktiva lancar tanpa memperhitungkan nilai persediaan.Kurangnya likuiditas menghalangi perusahaan untuk memperoleh keuntungan dari diskon atau kesempatan mendapatkan keuntungan.

Menurut Horne (2013:168), Perhitungan quick ratioadalah sebagai berikut.

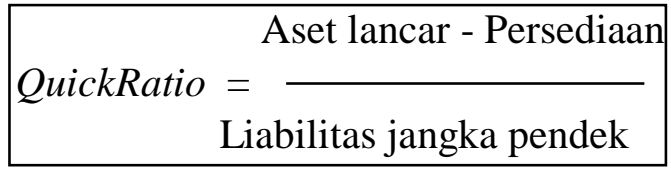

\section{Pengertian Times Interest Earned}

Menurut Brigham (2015:143), Times Interest Earned dihitung dengan membagi laba sebelum bunga dan pajak (EBIT) dengan beban bunga.Semakin besar rasio TIE berarti kemampuan perusahaan untuk membayar bunga semakin baik, dan peluang untuk mendapatkan tambahan pinjaman juga 
semakin tinggi, untuk mengoptimalkan pendapatan perusahaan.

Menurut Hery (2017:172), rumus untuk mencari rasio kelipatan bunga (times interest earned) dapat digunakan sebagai berikut:

$$
\mathrm{TIE}=\frac{\text { Laba sebelum bunga dan pajak }}{\text { Beban bunga }}
$$

Pengertian Return On Asset

Menurut Sudana menyatakan bahwa ROA menunjukan Kemampuan Perusahaan dengan menggunakan seluruh aktiva yang dimiliki untuk menghasilkan laba setelah pajak.Semakin tinggi rasio ini semakin tinggi pula jumlah laba bersih yang dihasilkan meningkat.

Menurut Murhadi (2013:64), ROA diperoleh dengan cara: $\mathrm{ROA}=\frac{\text { Net Income }}{\text { Total Asset }}$

\section{METODE PELAKSANAAN Pendekatan Penelitian}

Menurut Sugiyono (2012:35) pendekatan penelitian yang digunakan dalam penelitian ini adalah pendekatan kuantitatif yaitu sebagai metode penelitian yang berlandaskan pada filsafat positifisme, digunakan untuk meneliti pada populasi atau sampel tertentu, pengumpulan data menggunakan instrument penelitian, analisis data bersifat kuantitatif / statistic, dengan tujuan untuk menguji hipotesis yang telah ditetapkan.

\section{Jenis Penelitian}

Jenis penelitian ini adalah deskriptif kuantitatif.Menurut Sugiyono (2012:36) jenis penelitian deskriptif kuantitatif adalah jenis penelitian yang dimana data yang telah terkumpul dianalisis secara kuantitatif dengan menggunakan metode statistik deskriptif sehingga dapat disimpulkan hipotesis yang telah ditetapkan terbukti atau tidak.

\section{Populasi}

Menurut Sujarweni(2015:80) Populasi adalah keseluruhan jumlah yang terdiri atas: objekatausubjek yang mempunyai karakteristik dan kualitas tertentu yang ditetapkan oleh peneliti untuk diteliti dan kemudian ditarik kesimpulannya.Dalam penelitian ini yang menjadi populasi adalah perusahaan subsektor property dan real estate yang terdaftar di Bursa Efek Indonesia tahun 2013 - 2017 yang berjumlah 48 perusahan (lampiran).

\section{Sampel}

Menurut Sugiyono (2012:149), sampel merupakan bagian dari jumlah dan karakteristik yang dimiliki oleh populasi tersebut.

Menurut Wiratna Sujarweni (2015:88), sampling purposive adalah teknik penentuan sampel dengan pertimbangan atau kriteria-kriteria tertentu. Berikut ini kriteria pengambilan sampel penelitian adalah :

1. Perusahan sub sektor property dan real estate yang terdaftar di BEI pada tahun 2013 - 2017.

2. Perusahaanyang mempublikasikan laporan keuangan secara lengkap di Bursa Efek Indonesia pada tahun 2013-2017.

3. Perusahaanyang menghasilkan laba selama tahun 2013-2017.

Adapun perusahaan yang telah memenuhi kriteria adalah 12 perusahaan dikali 5 tahun menjadi 60 observasi pengamatan. 


\section{Identifikasi dan Definisi Variabel Penelitian}

Berdasarkan hipotesis pada bagian sebelumnya, identifikasi variabel penelitian dikelompokkan sebagai berikut :

1. Variabel Bebas $\left(\mathrm{X}_{1}\right)$ dalam penelitian ini adalah :fixed assets turnover, Variabel Bebas $\left(\mathrm{X}_{2}\right)$ dalam penelitian ini adalah : quick ratio dan Variabel Bebas $\left(\mathrm{X}_{3}\right)$ dalam penelitian ini adalah : times interest earned.

2. Variabel Terikat menurut Sugiyono (2012:59) Variabel terikat merupakan variabel yang dipengaruhi atau yang menjadi akibat, karena adanya variabel bebas. (y) dalam penelitian ini adalah : return on asset.

\section{Uji Asumsi Klasik}

Uji asumsi klasik dilakukan untuk mengetahui kondisi data yang ada agar dapat menentukan model analisis yang tepat. Data yang digunakan sebagai model regresi berganda dalam menguji hipotesis haruslah menghindari kemungkinan terjadinya penyimpangan asumsi klasik. Untuk mendapatkan model regresi yang baik harus terbebas dari penyimpangan data yang terdiri dari normalitas, multikolinieritas, heteroskedastisitas dan autokolerasi.

\section{Model Penelitian}

Menurut Siregar (2014:405), menyatakan model analisis data dalam penelitian ini merupakan analisis regresi berganda dimana penerapan metode regresi berganda jumlah variabel bebas (independent) yang digunakan lebih dari satu yang memengaruhi satu variabel tak bebas (dependent).

$$
\mathbf{Y}=\mathbf{a}+\mathbf{b}_{1} \mathbf{X}_{1}-\mathbf{b}_{2} \mathbf{X}_{2}+\mathbf{b}_{3} \mathbf{X}_{3}+\mathbf{e}
$$

Keterangan :

$$
\begin{array}{ll}
\mathrm{Y} & =\text { Return On Asset } \\
\mathrm{a} & =\text { Konstanta } \\
\mathrm{b}_{1}, \mathrm{~b}_{2}, \mathrm{~b}_{3}= & \text { Koefisien Regresi } \\
\mathrm{X}_{1} & =\text { Fixed Assets Turnover } \\
\mathrm{X}_{2} & =\text { Quick Ratio } \\
\mathrm{X}_{3} & =\text { Times Interest earned } \\
\mathrm{e} & =\text { Kesalahan } \quad \text { Penduga } \\
\text { (yang tidak } & \text { terungkap }=5 \%)
\end{array}
$$

\section{Koefisien Determinasi $\left(\mathbf{R}^{2}\right)$}

Menurut Ghozali (2016:95),

Koefisien determinasi ditujukan untuk mengukur seberapa jauh kemampuan model dalam menerangkan variasi terikat. Jika koefisien determinasi $\left(\mathrm{R}^{2}\right)$ semakin besar atau mendekati 1, maka dapat dikatakan bahwa kemampuan variabel bebas (X) adalah besar terhadap variabel terikat $(Y)$. Hal ini berarti model yang digunakan semakin kuat untuk menerangkan pengaruh variabel bebas yang diteliti dengan variabel terikat. Sebaliknya, jika koefisien determinasi $\left(\mathrm{R}^{2}\right)$ semakin kecil atau mendekati 0 maka dapat dikatakan bahwa kemampuan variabel bebas $(\mathrm{X})$ terhadap variabel terikat $(\mathrm{Y})$ semakin kecil.

\section{Pengujian Hipotesis secara Simultan (Uji-F)}

Menurut Ghozali (2016:96) uji statistik F pada dasarnya menunjukkan apakah semua variabel independen atau bebas yang dimasukkan dalam model mempunyai pengaruh secara bersamasama terhadap variabel dependen atau terikat.

\section{Pengujian Hipotesis secara Parsial (Uji-t) \\ Menurut Ghozali (2016:97) uji}


statistik t pada dasarnya menunjukkan seberapa jauh pengaruh satu variabel independen atau bebas secara individual dalam menerangkan variasi variabel dependen atau terikat.

\section{HASIL DAN PEMBAHASAN}

\section{Hasil Uji Asumsi Klasik}

\section{Uji Normalitas}

Uji normalitas bertujuan untuk menguji apakah model regresi, variable penganggu dan residual memiliki distribusi normal. Uji normalitas dapat dilihat dengan dua cara yaitu analisis grafik dan uji statistik.

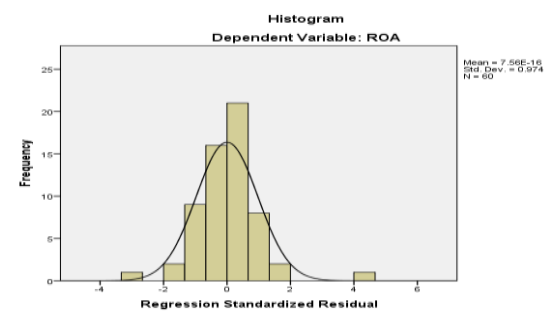

Gambar IV.1

\section{Uji Normalitas Histogram}

Pada Gambar IV.1 menunjukkan grafik histogram berdistribusi normal. Hal ini dapat dilihat dari grafik histogram yang menunjukkan data simestris tidak menceng ke kanan atau kiri.

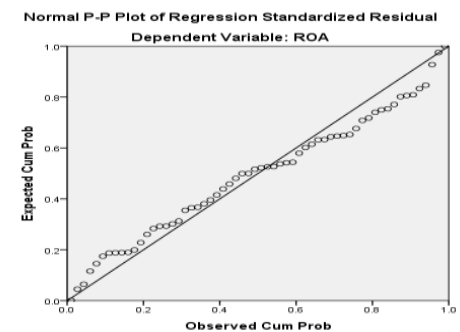

\section{Gambar IV.2}

\section{Uji Normalitas P-P Plot}

Pada Gambar IV.2 grafik P-Plot data berdistribusi normal akan membentuk satu garis lurus diagonal. Jika distribusi data residual normal, maka titik-titik pada grafik normal probability-plot menyebar mengikuti arah garis diagonalnya. Dari grafik normal probability-plot dan histogram pada gambar setelah ditransformasi dapat disimpulkan bahwa data berdistribusi secara normal.Berikut ini adalah hasil uji kolmogorov-smirnov :

Tabel IV.2

Uji Kolmogorov Smirnov

One-Sample Kolmogorov-Smirnov Test

\begin{tabular}{|ll|r|}
\hline & & $\begin{array}{c}\text { Unstandardized } \\
\text { Residual }\end{array}$ \\
\hline $\mathrm{N}$ & Mean & 60 \\
Normal & .0000000 \\
Parameters & Std. & .02529261 \\
& Deviation & .102 \\
Most Extreme & Absolute & .102 \\
Differences & Positive & -.085 \\
& Negative & .102 \\
Test Statistic & & $.197^{\mathrm{C}}$ \\
Asymp. Sig. (2-tailed)
\end{tabular}

a. Test distribution is Normal.

b. Calculated from data.

Hasil uji kolmogorov-smirnov setelah transformasi pada Tabel IV.2 menunjukkan nilai signifikansi sebesar 0,197 berada diatas 0,05 berarti data berdistribusi normal. Hal ini dapat dilihat pada nilai Asymp.Sig. (2-tailed) 0,197 lebih besar dari 0,05 sehingga berdistribusi normal. Dengan demikian data pada penelitian ini berdistribusi normal dan dapat digunakan untuk melakukan uji lainnya karena memiliki nilai signifikan $>0,05\left(\mathrm{H}_{0}\right.$ diterima $)$.

\section{Uji Multikolonieritas}

Uji multikolonieritas bertujuan untuk menguji apakah model regresi ditemukan adanya korelasi antar variabel bebas (independen). Untuk mendeteksi ada atau tidaknya multikolonieriyas didalam model regresi dapat dilihat dari nilai tolerance dan Variance Inflation Factor (VIF) cara pengambilan keputusannya yaitu nilai tolerance $\geq 0,10$ atau sama dengan nilai $\mathrm{VIF} \leq 10$. Berikut ini adalah hasil 
uji multikolnieritas sebelum dan setelah ditransformasi.

Tabel IV.3

Uji Multikolonieritas Coefficients $^{\mathrm{a}}$

\begin{tabular}{|c|c|c|c|}
\hline \multirow{2}{*}{\multicolumn{2}{|c|}{ Model }} & \multicolumn{2}{|c|}{ Collinearity Statistics } \\
\hline & & Tolerance & VIF \\
\hline \multirow[t]{3}{*}{1} & FAT & .972 & 1.028 \\
\hline & QR & .920 & 1.086 \\
\hline & TIE & .931 & 1.074 \\
\hline
\end{tabular}

Pada Tabel IV.3menunjukkan bahwa nilai tolerance yang diperoleh untuk variabel Fixed Assets Turnover adalah sebesar 0,972, variabel Quick Ratio adalah sebesar 0,931 dan variabel Times Interest Earned adalah sebesar 0,931. Nilai VIF untuk variabelFixed Assets Turnover adalah 1,028,variabel Quick Ratio adalah 1,086, dan variabel Times Interest Earned sebesar 1,074. Jadi dapat disimpulkan tidak ada multikolonieritas antar variabel independen dalam model regresi.

\section{Uji Autokorelasi}

Uji autokorelasi bertujuan untuk menguji apakah dalam model regresi linear korelasi antara kesalahan penganggu pada periode $\mathrm{t}$ dengan kesalahan pada t-1 (sebelumnya). Cara yang dapat digunakan untuk mendeteksi apakah terjadi autokorelasi atau tidak pada model regresi adalah dengan uji Durbin-Watson.Berikut uji autokorelasi dengan Durbin-Watson:

Tabel IV.4

Uii Durbin Watson

Model Summary ${ }^{\mathrm{b}}$

\begin{tabular}{|l|c|}
\hline Model & Durbin-Watson \\
\hline 1 & 1.941 \\
\hline
\end{tabular}

a. Predictors: (Constant), TIE, FAT, QR

b. Dependent Variable: ROA

dari tabel DW pada tingkat kekeliruan
$5 \%$ untuk jumlah variabel independen $=$ 3 dan jumlah pengamatan $\mathrm{n}=60$ diperoleh batas bawah nilai tabel $(\mathrm{dl})=$ 1,4797 dan batas atasnya $(\mathrm{du})=1,6889$ , sehingga nilai 4-du $=2,3111$. dapat diketahui bahwa nilai DW pada penelitian ini adalah $\mathrm{du}<\mathrm{d}<4$-du atau berada di antara 1,6889<1,941<2,3111, maka dapat disimpulkan bahwa model persamaan regresi tersebut tidak mengandung masalah autokorelasi.

\section{Uji Heteroskedastisitas}

Uji heteroskedastisitas bertujuan untuk menguji apakah model regresi terjadi ketidaksamaan variance dari residual satu pengamatan ke pengamatan lain. Jika variance dari residual satu pengamatan ke pengamatan lain tetap maka disebut homoskedastisitas dan jika berbeda disebut heteroskedatastisitas. Model Regresi yang baik adalah terjadi homoskedastisitas atau tidak terjadi heteroskedastisitas.

Berikut ini hasil uji grafik scatter plot sebelum dan setelah di transformasi:

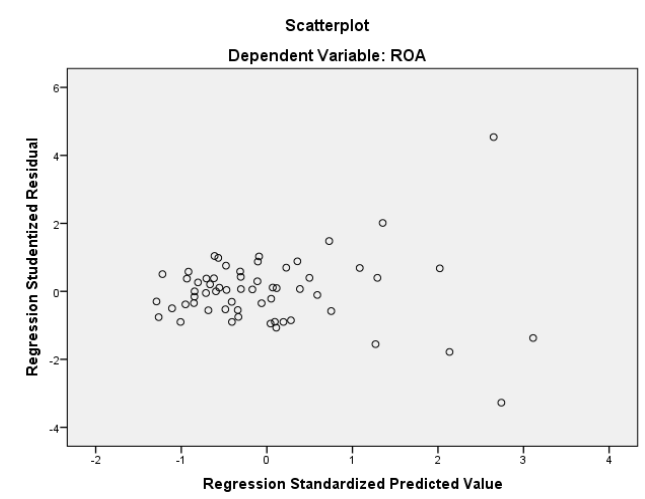

Gambar IV.3

\section{Uji Scatterplot}

Pada Gambar IV.3 diatas menunjukkan tidak ada pola yang jelas, serta titik-titik menyebar diatas dan dibawah angka 0 pada sumbu Y, maka 
tidak terjadi heteroskedastisitas.Berikut ini hasil uji white:

\section{Tabel IV.5}

\section{Uji White}

\begin{tabular}{|l|c|r|r|r|}
\multicolumn{5}{c|}{ Model Summary $^{\text {b }}$} \\
\hline Model & $\mathrm{R}$ & $\begin{array}{c}\mathrm{R} \\
\text { Square }\end{array}$ & $\begin{array}{c}\text { Adjusted } \\
\text { R Square }\end{array}$ & $\begin{array}{r}\text { Std. Error of } \\
\text { the Estimate }\end{array}$ \\
\hline 1 & $.872^{\mathrm{a}}$ & .760 & .728 & .00090 \\
\hline
\end{tabular}

a. Predictors: (Constant), FAT.QR.TIE, QR, FAT2, TIE, FAT, TIE2, QR2

b. Dependent Variable: RES1_2

Dari Tabel IV.5 hasil R Square sebesar 0,760 dengan jumlah sampel 60 dan jumlah variabel ada 4. Hasil chisquare hitung yaitu sebesar $(60 \times 0,760)$ $=45,6$. Sedangkan hasil chi-square tabel dilihat dari pada urutan ke $60-4$ $($ variabel $)=56$ dengan tingkat 0,05 , maka diperoleh nilai pada tabel sebesar 74,46832. dengan demikian dapat disimpulkan tidak terjadi heterokedastisitas karena hasil chisquare hitung lebih kecil dari chisquare tabel $\left(\mathrm{C}^{2}\right.$ hitung $<\mathrm{C}^{2}$ tabel).

\section{Hasil Analisis Data}

\section{Analisis Regresi Linear Berganda}

Analisis linear berganda bertujuan untuk mengetahui besarnya pengaruh Fixed Assets Turnover, Quick Ratio dan Times Interest Earned terhadapReturn On Asset. Hasil analisis linear berganda dapat dilihat pada Tabel IV.6 dibawah ini:

\section{Tabel IV.6}

Regresi Linear Berganda Coefficients $^{a}$

a. Dependent Variable: ROA

\begin{tabular}{|c|c|c|c|}
\hline \multirow{2}{*}{\multicolumn{2}{|c|}{ Model }} & \multicolumn{2}{|c|}{$\begin{array}{l}\text { Unstandardized } \\
\text { Coefficients }\end{array}$} \\
\hline & & $B$ & Std. Error \\
\hline \multirow[t]{4}{*}{1} & (Constant) & .027 & .007 \\
\hline & SQRT_ITO & .000 & .001 \\
\hline & SQRT_DAR & -.002 & .002 \\
\hline & SQRT CR & .008 & .001 \\
\hline
\end{tabular}

Berdasarkan Tabel IV.6 maka diperoleh persamaan linear berganda hipotesis penelitian sebagai berikut:

$\mathrm{ROA}=0,027+0,000 \mathrm{FAT} \quad-0,002 \mathrm{QR}$ $+0,008 \mathrm{TIE}$

\section{Koefisien Determinasi}

Koefisien determinasi $\left(\mathrm{R}^{2}\right)$ dilakukan untuk mengukur seberapa jauh kemampuan model dalam menerangkan variasi variabel dependen. Namun dalam penelitian ini digunakan nilai Adjusted $\mathrm{R}^{2}$ untuk dapat mengevaluasi mana model terbaik. Tidak seperti $\mathrm{R}^{2}$, nilai adjusted $\mathrm{R}^{2}$ dapat naik atau turun apabila satu variabel indenpenden ditambahkan kedalam model. Nilai Adjusted R Square digunakan untuk mengukur seberapa besar pengaruh informasi Fixed Assets Turnover, Quick Ratio dan Times Interest Earned terhadap Return On Asset pada perusahaan subsektor property dan real estate yang terdaftar di Bursa Efek Indonesia periode 20132017. Hasil perhitungannya adalah sebagai berikut

\section{Tabel IV.7}

\section{Koefisien Determinasi} Model Summary ${ }^{\mathrm{b}}$

\begin{tabular}{|l|c|r|c|}
\hline Model & $\mathrm{R}$ & $\mathrm{R}$ Square & $\begin{array}{c}\text { Adjusted R } \\
\text { Square }\end{array}$ \\
\hline 1 & $783^{\mathrm{a}}$ & .613 & .592 \\
\hline
\end{tabular}

a. Predictors: (Constant), TIE, FAT, QR

b. Dependent Variable: ROA

Berdasarkan Tabel IV.7 diperoleh nilai Adjusted $\mathrm{R}$ Square sebesar 0,592atau 59,2\% yang berarti perubahan variabel Return On Asset dapat dijelaskan oleh variasi variabel Fixed Assets Turnover, Quick Ratio dan Times Interest Earned, sedangkan sisanya sebesar $40,8 \%$ merupakan variabel dari variabel bebas lain yang 
tidak diteliti dalam penelitian ini seperti Inventory Turnover,Cash Ratio, Current Ratio,Debt to Equity Ratio.

\section{Pengujian Hipotesis Secara Simultan (Uji F)}

Uji hipotesis secara simultan bertujuan menunjukkan apakah semua variabel independen atau bebas yang dimasukkan dalam model mempunyai pengaruh secara bersama-sama terhadap variabel dependen (terikat).

Tabel IV.8

Uji F (Simultan)

ANOVA $^{\mathrm{a}}$
\begin{tabular}{|l|c|c|}
\hline Model & $\mathrm{F}$ & Sig. \\
\hline $1 \quad \begin{array}{l}\text { Regression } \\
\text { Residual } \\
\text { Total }\end{array}$ & 29.588 & $.000^{\mathrm{b}}$ \\
& & \\
\hline
\end{tabular}

a. Dependent Variable: ROA

b. Predictors: (Constant), TIE, FAT, QR

Berdasarkan Tabel IV.8, dapat dilihat hasil $F_{\text {hitungadalah sebesar }}$ 29,588dengan tingkat signifikan 0,000 dan dengan menggunakan tabel $F$ adalah df1 $=\mathrm{k}(4)-1=3$ dan df2 $=$ $\mathrm{n}(60)-\mathrm{k}(4)=56$ adalah 2,77 , jadi nilai yang diperoleh $\mathrm{F}_{\text {tabel }}$ sebesar 2,78 maka hasilnya adalah $\quad \mathrm{F}_{\text {hitung }}>\mathrm{F}_{\text {tabel }}$ $(29,588>2,77)$ dengan tingkat signifikan $0,000<0,05$. Hal ini menunjukkan bahwa hasil hipotesis penelitian $\mathrm{H}_{0}$ ditolak dan Ha diterima artinya Fixed Assets Turnover, Quick Ratio dan Times Interest Earned secara simultan berpengaruh dan signifikan terhadap Return On Asset pada perusahaan sub sektor property dan real estate yang terdaftar di Bursa Efek Indonesia periode 2013-2017.

\section{Pengujian Hipotesis Secara Parsial (Uji t)}

Uji t (parsial) digunakan untuk mengetahui pengaruh masing-masing terhadap Return On Asset dengan tingkat signifikan 5\%. Hasil pengujian dengan uji $t$ adalah sebagai berikut

\section{Tabel IV.9}

Uji t (Parsial)

Coefficients $^{\mathrm{a}}$

\begin{tabular}{|ll|c|c|}
\hline Model & & $\mathrm{t}$ & \multicolumn{1}{c|}{ Sig. } \\
\hline 1 & (Constant) & 3.688 & .001 \\
& FAT & -.411 & .683 \\
& QR & -.643 & .523 \\
& TIE & 8.944 & .000 \\
\hline
\end{tabular}

a. Dependent Variable: ROA

Dari Tabel IV.9 dari hasil pengujian secara parsial diatas, dapat dilihat bahwa :

1. Pengaruh Fixed Assets Turnover terhadap Return On Asset

Variabel Fixed Assets Turnover punyai nilai tabel sebesar 2,00324(uji $\mathrm{t}=\mathrm{n}(60)-\mathrm{k}(4)=$ $56)$, maka $-\mathrm{t}_{\text {hitung }}<-\mathrm{t}_{\text {tabel }}$ adalah(0,411>-2,00324)dengan

signifikan 0,683> 0,05. Hasil hipotesis penelitian ini adalahHa ditolak dan $\mathrm{H}_{0}$ diterima artinya secara parsial Fixed Assets Turnovertidak

berpengaruhdantidak signifikan terhadapReturn On Asset pada perusahaan sub sektor property dan real estate yang terdaftar di Bursa Efek Indonesia periode 2013-2017.

2. Pengaruh Quick Ratio terhadap Return On Asset

Variabel Quick Ratio mempunyai nilai tabel sebesar 2,00324, maka $-t_{\text {hitung }}<-t_{\text {tabel }}$ adalah(-0,643>-2,00324)dengan nilai signifikan $0,534>0,05$. 
Hasil hipotesis penelitian ini adalah $\mathrm{Ha}$ ditolak dan $\mathrm{H}_{0}$ diterima artinya secara parsial Quick Ratiotidak berpengaruhdantidak signifikan terhadap Return On Asset pada perusahaan sub sektor property dan real estate yang terdaftar di Bursa Efek Indonesia periode 2013-2017.

3. Pengaruh Times Interest Earned terhadap Return On Asset

Variabel Times Interest Earned mempunyai nilai tabel sebesar 2,00324 , maka $-t_{\text {hitung }}<-t_{\text {tabel }}$ adalah $(8,944>2,00324)$ dengan

nilai signifikan $0,000<0,05$. Hasil hipotesis penelitian ini adalah $\mathrm{Ha}$ diterima dan $\mathrm{H}_{0}$ ditolak artinya secara parsial Times

Interest

Earnedberpengaruh positif dan signifikanterhadap Return On Asset pada perusahaan sub sektor property dan real estate yang terdaftar di Bursa Efek Indonesia periode 2013-2017.

\section{Pengaruh Fixed Assets}

TurnoverTerhadap Return On Asset

Berdasarkan hasil uji secara parsial menunjukan bahwa Fixed Assets Turnovertidak berpengaruh dan tidak signifikan terhadap Return On Asset.

Hasil penelitan ini tidak sejalan dengan teori Menurut Kodrat (2010:238), Semakin tinggi rasio perputaran aset tetap berarti semakin efektif penggunaan aktiva tetap bersih untuk menghasilkan penjualan (pendapatan).

Hasil penelitian inisejalan dengan penelitian Yan Andari, dkk
(2016) yang menyatakan bahwa secara parsial Fixed Assets Turnovertidak berpengaruh signifikan terhadap Return On Asset.

Sehingga padaperusahaan sub sektor property dan real estatetidak perlu takut tentang perputaran aktiva tetap, tetapi perusahaan tetap harus mengevaluasi kemampuan perusahaan menggunakan aktivanya secara efektif untuk meningkatkan pendapatan.

\section{Pengaruh Quick RatioTerhadap Return On Asset}

Berdasarkan hasil uji secara parsial menunjukan bahwaQuick Ratiotidak berpengaruh dan tidak signifikan terhadap Return On Asset.

Hasil penelitan ini tidak sejalandengan teori Menurut Horne (2013:163), semakin besar likuiditas perusahaan, semakin kuat kondisi keuangan keseluruhan perusahaan dan semakin besar profitabilitas perusahaan.

Hasil penelitian ini tidak sejalan dengan penelitian Utami Prihati, dkk (2017) yang menyatakan bahwa secara parsial Quick Ratioberpengaruh negatif signifikan terhadap Return On Asset.

Sehingga padaperusahaan sub sektor property dan real estate tidak ragu tentang likuiditas (quick ratio) karena semuanya utang jangka pendek pasti dapat dibayar tepat waktu.

\section{Pengaruh Times Interest Earned Terhadap Return On Asset}

Berdasarkan hasil uji secara parsial menunjukan bahwaTimes Interest Earnedber pengaruh positif dan signifikan terhadap Return On Asset.

Hasil penelitan inisejalandengan teori Menurut Sudana (2015:23), Semakin besar rasio TIE berarti kemampuan perusahaan untuk membayar bunga semakin baik, dan 
peluang untuk mendapatkan tambahan pinjaman juga semakin tinggi, untuk mengoptimalkan pendapatan perusahaan.

Hasil penelitian inisejalan dengan penelitian Reni Yuli, dkk (2016) yang menyatakan bahwa secara parsial Times Interest Earned berpengaruh positif signifikan terhadap Return On Asset.

Sehingga padaperusahaan sub sektor property dan real estate yang semakin tinggi rasio TIE, semakin besar kemungkinan perusahaan dapat membayar bunga pinjaman dan dapat menjadi ukuran untuk memperoleh tambahan pinjaman baru dari kreditor, sehingga dapat meningkatkan keuntungan.

Pengaruh Fixed Assets Turnover, Quick Ratiodan Times Interest EarnedTerhadap Return On Asset

Berdasarkan hasil pengujian hipotesis secara simultan untuk variabel Fixed Assets Turnover, Quick Ratio, dan Times Interest Earned terhadap Return On Asset diperoleh nilai $\mathrm{F}_{\text {hitung }}$ adalah sebesar 29,588 dengan nilai signifikansi $\quad 0,000 \quad$ sedangkan $\quad F_{\text {tabel }}$ adalah sebesar 2,77 dengan signifikansi 0,05. Dengan demikian maka kesimpulannya adalah $\mathrm{F}_{\text {hitung }}>\mathrm{F}_{\text {tabel }}$ yaitu 29,588>2,77 maka keputusannya adalah $\mathrm{H}_{0}$ ditolak dan $\mathrm{Ha}$ diterima, artinya variabel Fixed Assets Turnover, Quick Ratio dan Times Interest Earnedsecara simultan berpengaruh positif dan signifikan terhadap Return On Asset pada perusahaan sub sektor property dan real estate yang terdaftar di Bursa Efek Indonesia periode 20132017

\section{KESIMPULAN}

Dari hasil penelitian ini diperoleh kesimpulan sebagai berikut:

1. Dari hasil pengujian yang dilakukan secara parsialFixed Assets Turnover tidak berpengaruh dan tidak signifikan terhadap Return On Asset pada perusahaan sub sektor property dan real estate yang terdaftar di Bursa Efek Indonesia periode 2013-2017.

2. Dari hasil pengujian yang dilakukan secara parsial Quick Ratiotidak berpengaruh dan tidak signifikan terhadap Return On Assetpada perusahaan sub sektor property dan real estate yang terdaftar di Bursa Efek Indonesia periode 2013-2017.

3. Dari hasil pengujian yang dilakukan secara parsial Times Interest Earned berpengaruh positif dan signifikan terhadap Return On Asset pada perusahaan sub sektor property dan real estate yang terdaftar di Bursa Efek Indonesia periode 20132017.

4. Dari hasil pengujian yang dilakukan secara simultan Fixed Assets Turnover, Quick Ratio dan Times Interest Earned berpengaruh dan signifikan terhadap Return On Asset pada perusahaan sub sektor property dan real estate yang terdaftar di Bursa Efek Indonesia periode 2013-2017.

\section{DAFTAR PUSTAKA}

Brigham dan Houston. 2015. Dasardasar Manajemen Keuangan. 
Buku 1. Ed. 11, Jakarta: Salemba Empat.

Fahmi, Irham. 2016. Pengantar Manajemen Keuangan Teori dan Soal Jawab. Cetakan Ke-5. Bandung: Alfabeta.

Ghozali, Imam. 2016. Aplikasi Analisis Multivariate dengan Program IBM SPSS 23. Semarang: Penerbit Universitas Diponegoro.

Hanafi, Mamduh M \& Abdul Halim. 2016. Analisis Laporan Keuangan. Ed. 5, Cetakan Ke-1. Yogyakarta: UPP STIM YKPN.

Hery. 2017. Analisis Laporan Keuangan.Cetakan Ke-2. Jakarta: PT Grasindo.

Hermanto, Bambang \& Mulyo Agung. 2015. Analisa Laporan Keuangan. Cetakan Ke-4. Jakarta: Lentera Ilmu Cendekia.

Horne, James C. Van \& John M. Wachowicz. 2013. Prinsip Prinsip Manajemen Keuangan. Buku 1. Ed. 13, Jakarta: Salemba Empat.

Jumingan. 2014. Analisis Laporan Keuangan. Jakarta: PT Bumi Aksara.

Kasmir. 2012. Analisis Laporan Keuangan. Cetakan Ke-5. Jakarta: PT Grafindo Persada.

Kodrat, David Sukardi \& Kurniawan Indonanjaya. 2010. Manajemen
Investasi Pendekatan Teknikal dan Fundamental untuk Analisis Saham.Cetakan Ke-1. Yogyakarta: Graha Ilmu.

Munawir.2014. Analisa Laporan Keuangan, Cetakan Ke-17. Yogyakarta: Liberty.

Murhadi, Werner R. 2015. Analisis Laporan Keuangan Proyeksi dan Valuasi Saham. Jakarta: Salemba Empat.

Prihadi, Toto. 2013. Analisis Laporan Keuangan Teori dan Aplikasi.Cetakan Ke-3. Jakarta: PPM.

Raharjaputra, Hendra S. 2011. Buku Panduan Praktis Manajemen Keuangan dan Akutansi untuk Eksekutif Perusahaan.Cetakan Ke-1. Jakarta: Salemba Empat.

Sanusi, Anwar. 2011. Metode Penelitian Bisnis. Cetakan Ke-1. Jakarta: Salemba Empat.

Sartono, R. Agus. 2010. Manajemen Keuangan Teori dan Aplikasi.Cetakan Ke- 4.

Yogyakarta:

BPFEYOGYAKARTA.

Sawir, Agnes. 2017. Analisis Kinerja Keuangan dan Perencanaan Keuangan Perusahaan.

Jakarta: PT Gramedia Pustaka Utama.

Subramanyam \& John J. Wild, 2014.Analisis Laporan Keuangan. Ed. 10, Buku 1. Jakarta: Salemba Empat. 
2013.

Analisis Laporan Keuangan.

Ed. 10, Buku $2 . \quad$ Jakarta:

Salemba Empat.

Sudana, I Made. 2015. Manajemen

Keuangan Perusahaan Teori dan Praktik. Surabaya:

Erlangga.

Sugiyono. 2012. Metode Penelitian

Bisnis. Bandung: CV Alfabeta.

Sujarweni, Wiratna. 2015.Metodologi

Penelitian Bisnis dan

Ekonomi.Cetakan Ke-1.

Yogyakarta: Pustaka Baru Press.

Wiyono, Gendro \& Hadri kusuma.2017.

$\begin{array}{lc}\text { Manajemen } & \text { Keuangan } \\ \text { Lanjutan } & \text { Berbasis } \\ \text { Corporate Value Creation. } & \text { Vre } \\ \text { Yogyakarta: UPP STIM YKPN. }\end{array}$

Zulganef. 2013. Metode Penelitian

Sosial dan Bisnis. Cetakan Ke-

2. Yogyakarta: Graha Ilmu. 